\title{
PERSEPSI MAHASISWA MENGENAI PENGARUH IPK (INDEKS PRESTASI KUMULATIF), PENGHARGAAN FINANSIAL DAN LINGKUNGAN KERJA TERHADAP PEMILIHAN PROFESI AKUNTAN PUBLIK
}

\section{PERCEPTION OF STUDENT CONCERNING INFLUENCE OF IPK ( CUMULATIVE INDEX ACHIEVEMENT), APPRECIATION OF FINANSIAL AND ENVIRONMENT WORK TO ELECTION OF PROFESSION PUBLIC ACCOUNTANT}

\author{
A. Lasmana; Rafidah \\ Jurusan Akuntansi Fakultas Ekonomi Universitas Djuanda Bogor \\ E-mail : andy.lasmana@unida.ac, rafidah@unida.ac.id
}

\begin{abstract}
Election of public accountant profession become matter of necessary for accounting majors student as labour candidate having completed its study. Public accountant required company to give service activities about inspection of reporting of monetary information hit equity of financial statement.. Population in this research is Program Study student of S-1 Accounting College which is have active status to in Town of Bogor that is 857 student. Intake of sample done by using method of proportionate sampling random stratified, of the method can be determined by the amount of sample counted 273 by using primary date and instrument of questionnaires. Technique analyse date the used is technique analyse multiple regression. Result of research of indicates that Program Study Accounting student in Town of Bogor woman majority which is have age to between 21-25 year with previous education background of majors of IPS. As for result of student comments of Perception of Student concerning IPK (cumulative achievement index), Appreciation of Finansial and Environment Job have an effect on either through and also simultaneous of partial to election of Profession Public Accountant with contribution equal to 40,2 gratuity and of IPK become dominant variable.
\end{abstract}

Keyword : Perception of IPK, Appreciation, Environmental of Job and Profession Accounting.

\section{ABSTRAK}

Pemilihan profesi akuntan publik menjadi hal penting bagi mahasiswa jurusan akuntansi sebagai calon tenaga kerja setelah menyelesaikan studinya. Akuntan publik dibutuhkan perusahaan untuk memberikan pelayanan jasa tentang pemeriksaan pelaporan informasi keuangan mengenai kewjaran laporan keuangan. Populasi dalam penelitian ini adalah mahasiswa Program Studi S1 Akuntansi Perguruan Tinggi yang berstatus aktif di Kota Bogor yaitu 857 mahasiswa. Pengambilan sampel dilakukan dengan menggnakan metode proportionate stratified random sampling, dari metode tersebut dapat ditentukan jumlah sampel sebanyak 273 dengan menggunakan data primer dan instrumen kuesioner. Teknik analisis data yang digunakan adalah teknik analisis regresi berganda. Hasil penelitian menunjukan bahwa mahasiswa Program Studi Akuntansi di Kota Bogor mayoritas perempuan yang berusia antara 21-25 tahun dengn latar belakang pendidikan sebelumnya dari jurusan IPS. Adapun hasil tanggapan mahasiswa atas Persepsi Mahasiswa mengenai IPK (indeks prestasi kumulatif), Penghargaan Finansial dan Lingkungan Kerja berpengaruh baik secara simultan maupun parsial terhadap pemilihan Profesi Akuntan Publik dengan kontribusi sebesar 40,2 persen dan IPK menjadi variabel yang dominan.

Kata kunci : Persepsi IPK, Penghargaan, Lingkungan Kerja dan Profesi Akuntansi. 


\section{PENDAHULUAN}

Ekonomi dan keuangan adalah peran penting didalam pertumbuhan globalisasi, sejalan dengan kemajuan pesat dunia teknologi dan informasi, ilmu akuntansi berkembang dengan sangat baik. Dalam perkembangan ini membuat peran AP (akuntan publik) semakin penting, permintaan akan jasa professional akuntansi semakin meningkat. Penyebab tingginya jasa profesi akuntan publik di Indonesia adalah semakin berkembangnya perusahaan di Indonesia. Tantangan bagi seorang profesional bidang akuntan di Indonesia akan lebih kompetitif dengan berlakunya pasar bebas sektor jasa dalam MEA 2015.

Indonesia memiliki 265.000 mahasiwa bidang studi akuntansi yang berasal dari 589 perguruan tinggi seluruh Indonesia. Menurut data World Bank tahun 2014 lulusan mahasiswa bidang studi akuntansi seluruh negara ASEAN rata-rata setiap tahunnya berjumlah 77.330 orang. Indonesia menjadi peringkat pertama terbanyak penghasil lulusan Akuntansi dengan kontribusi 45\% dari jumlah keseluruhan lulusan akuntansi ASEAN, dan setiap tahun Indonesia meloloskan 35.000 mahasiswa akuntansi. Jumlah tersebut menunjukkan Indonesia mempunyai peluang besar menjadi negara dengan profesi akuntan terkuat di regional. Namun dari jumlah tersebut, baru sekitar 24 ribu orang yang tercatat sebagai Akuntan Profesional bernaung di organisasi profesi IAI (Ikatan Akuntan Indonesia). Menurut data IAI total AP (akuntan publik) di Indonesia tahun 2011 yaitu sebanyak 995 orang, tahun 2012 sebanyak 1.016 orang dan pada tahun 2013 sebanyak 1.019 orang. Jumlah tersebut menggambarkan pertumbuhan jtotal AP di Indonesia tidak bertambah signifikan disetiap tahunnya, dan jumlah profesi ini ada di kisaran seribuan dan masih tertinggal bila melihat beberapa Negara ASEAN lainnya. Tahun 2012 total akuntan publik di Malaysia tercatat sekitar 2.500 orang, dan di Thailand tercatat sebanyak 6.000 orang, sementara itu tercatat 4.941 orang total AP (akuntan publik) di Filipina (http://www.iaiglobal.or.id).

Akuntan publik menjadi profesi yang mungkin dimiliki oleh seorang lulusan akuntansi, dan profesi merupakan penguasaan suatu keahlian tertentu yang diperoleh melewati pelatihan serta pendidikan sehingga memenuhi standar keahlian dikeahlian terpilih. Mulyadi (2002:4), pekerjaan AP (akuntan publik) adalah profesi kepercayaan kalangan masyarakat, dari profesi inilah masyarakat menantikan sebuah penilaian yang bebas dan bukan memihak kepada informasi yang dipaparkan manajemen perusahaan pada laporan keuangan. Semua standar dan ketentuan diatur oleh pemerintah dari berbagai regulasi bagi seorng akuntan publik tersebut adalah sesuatu yang tidak dapat dicapai tanpa pendidikan yang baik, mengingat perusahaan - perusahaan global banyak mensyaratkan IPK 3,25 ke atas sebagai syarat administrasi mendaftar test. Mladenovic (2000) dan zhang (2006) dalam Odia (2013:90), faktor keterampilan kuantitatif dan tantangan intelektual juga mempengaruhi pilihan mahasiswa. Profesi akuntan publik termasuk profesi terbaik dalam hal finansial nya karena selain menjadi jasa audit profesi ini dapat berprofesi sebagai jasa konsultasi manajemen, dan kondisi ini mampu menjadi pertimbangan minat seseorang menjadi akuntan sektor publik. Asmoro dkk, (2016:70), Penghargaan finansial atau gaji dipertimbangkan saat memilih profesi karena tujuan utama seseorang bekerja adalah memperoleh gaji. Proses yang seharusnya dilewati guna menjadi akuntan disektor publik tidaklah mudah dan lingkungan dalam pekerjaan sebagai salah satu yang dipertimbangkan karena lingkungan kerja profesi akuntan disektor publik sendiri lebih banyak dituntut demi menghadapi tantangan pada bervariasinya jasa yang ditawarkan klien dapat menimbulkan berbagai macam tekanan kerja demi menggapai hasil yang maksimal seimbang dengan keinginan klien. Sutrisno (2009:116) lingkungan kerja merupakan sarana prasarana kerja berada disekitar pekerja yang sedang melaksanakan pekerjaan bisa mempengaruhi pelaksanaan pekerjaan. Situasi kerja meliputi sifat kerja (atraktif, rutin dan sering lembur), jenjang persaingan antar karyawan serta tekanan kerja menjadi prihal mengenai lingkungan pekerjaan yang nantinya dipertimbangkan seseorang dalam memlih pekerjaan. Stolle dalam Putra (2011:4), pekerjaan menjadi akuntan disektor publik cenderung atraktif, membutuhkan lebih bnyak waktu, nilai persaingan dan besarnya tekanan dalam memberikan produktvitas kerja yang lebih maksimal. 
Kota Bogor ialah beberapa dari banyaknya kota di Indonesia lalu menjadi pilihan calon mahasiswa untuk melanjutkan pendidikannya, hal ini dibuktikan oleh data yang dipublikasi Bogor dalam angka 2015 bahwa jumlah mahasiswa di Kota Bogor yang bermula dari seluruh program studi pada tahun 2013 sebanyak 24.547 mahasiswa dan tahun 2014 sebanyak 49.967 mahasiswa dengan banyaknya pilihan studi yang terdapat di Kota Bogor dari sekolah tinggi, universitas hingga Institut. Adapun jumlah mahasiswa aktif S.1 program studi akuntansi yang berstatus aktif di Kota Bogor menurut observasi yaitu sebanyak 3.145 mahasiswa dan menyebar dibeberapa perguruan tinggi, antara lain : Universitas Pakuan, STIE Kesatuan, Universitas Nusa Bangsa dan STIE Triguna, dan ini menggambarkan bahwa mahasiswa aktif perguruan tinggi program studi S.1 akuntansi dapat sangat berpotensi menjadi seorang akuntan publik.

Penelitian ini menajdi menarik untuk dilakukan karena sejauh ini menurut data BPK (Badan Pemeriksa Keuangan) 2017, belum kedapatan KAP (Kantor Akuntan Publik) di Kota Bogor dan tercantum di BPK (Badan Pemeriksa Keuangan), dan menurut data IAPI (Institut Akuntan Publik Indonesia) (2016), hanya terdapat 3 orang yang berprofesi sebagai akuntan publik yang mempunyai izin dan tercantum di Kota Bogor. Hal ini menggambarkan minimnya minat mahasiswa bidang studi akuntansi di Kota Bogor untuk berprofesi akuntan publik padahal profesi ini dapat di serap oleh perusahan-perusahaan ternama di Kota Bogor, namun hingga kini lulusan studi akuntansi di Kota Bogor belum menunjukan kontribusinya untuk menentukan profesi akuntan disektor publik.

Berdasarkan dengan uraian tersebut, penulis tertarik melakukan penelitian berjudul "Persepsi Mahasiswa Mengenai Pengaruh IPK (Indeks Prestasi Kumulatif), Penghargaan Finansial, dan Lingkungan Kerja Terhadap Pemilihan Profesi Akuntan Publik" ialah :

Tujuan dari dilakukannya penilitian ini

1. Untuk mengetahui karakteristik dan deskripsi mahasiswa program studi akuntansi S-1 di Kota Bogor.

2. Untuk mengetahui apakah persepsi mahasiswa mengenai IPK (indeks prestasi kumulatif), penghargaan finansial dan lingkungan kerja berpengaruh secara simultan terhadap pemilihan profesi akuntan publik.

3. Untuk mengetahui apakah persepsi mahasiswa mengenai IPK (indeks prestasi kumulatif), penghargaan finansial dan lingkungan kerja berpengaruh secara parsial terhadap pemilihan profesi akuntan publik.

4. Untuk mengetahui faktor yang paling dominan dalam mempengaruhi pemilihan profesi akuntan publik.

Dengan dilakukannya penelitian ini diharapkan mampu menjadi manfaat baik, bagi peneliti, bagi mahasiswa studi akuntansi , lingkungan akademik dan juga bagi akuntan publik. Karena penelitian ini mampu memperluas wawasan penulis dan menambh ilmu pengetahuan, menambah informasi bagi mahasiswa akuntansi mengenai menentukan profesi akuntan disektor publik, untuk proses pengembangan ilmu pengetahuan bagi lingkungan akademik khususnya dibidang akuntansi dan audit berkaitan dengan akuntan publik. Dan juga diharapkan dapat menjadi sumber informasi bagi lembaga bersangkutan dengan penentuan kebijakan bagi akuntan publik guna meningkatkan profesionalisme dan persaingan akuntan publik.

\section{TINJAUAN TEORI DAN PENGEMBANGAN HIPOTESIS}

\section{Persepsi}

persepsi adalah proses kognitif yang dialami setiap orang mengenai pemahaman disetiap informasi tentang lingkungannya melewati panca inderanya (mendengar, melihat, mencium, menyentuh dan merasakan). Sedangkan persepsi melibatkan kognisi tingkat tinggi dalam menginterprestasian terhadap informasi sensorik. Pada dasarnya, sensasi mengacu pada pendeteksian dini terhadap stimuli, persepsi mengacu pada interprestasi hal-hal yang kita indera (Salso et, all.,2007:75) .

\section{IPK (Indeks Prestasi Kumulatif)}

IPK yaitu indeks prestasi yang dihitung pada akhir dalam program pendidikan lengkap atau pada akhir smester 2 dan selanjutnya untuk keseluruhan mata kuliah setelah diambilnya, Siregar (2006). KBBI (Kamus Besar Bahasa Indonesia) edisi 3 (2007:910), 
prestasi ialah kemampuan keahlian dan ilmu pengetahuan yang ditingkatkan melalui pelajaran, lazimnya diperlihatkan dengan hasil tes berwujud angka yang diberikan guru.

\section{Penghargaan Finansial}

Penghargaan finansial merupakan total seluruh pengeluaran perusahan untuk karyawan guna memberikan timbalbalik kepada pekerjaan yang dilakukannya. Veithzal (2011:762), mendefinisikan penghargaan finansial sebagai balas jasa berupa uang lalu diterima karyawan karena kedudukannya di perusahaan yang memberikan kontribusi demi meraih tujuan perusahaan.

\section{Lingkungan Kerja}

Lingkungan kerja merupakan suatu yang selalu dipertimbangkan calon karyawan dalam memutuskan suatu pekerjaan. Sutrisno (2009:116), lingkungan kerja merupakan sarana prasarana pekerjaan dan berada disekitar pekerja dalam mengerjakan pekerjaan lalu mampu mempengaruhi pelaksanaan pekerjaan. Kondisi pekerjaan yang bersifat (atraktif, rutin juga sering lembur), nilai persaingan pekerja dan beban pekerjaan menjadi prihal mengenai lingkungan pekerjaan yang nantinya dipertimbangkan seseorang dalam memlih pekerjaan.

\section{Profesi Akuntan Publik}

Profesi akuntan disektor publik ialah akuntan yang pekerjaannya dilakukan di KAP (kantor akuntan publik). Macam-macam pekerjaan dapat dilakukan kantor akuntan publik diantaranya yaitu melakukan pemeriksaan laporan keuangan dan juga malakukan sebuah konsultasi di bidang keuangan. Menurut IAI (2016:44), akuntan profesional dalam praktik publik merupakan akuntan profesional dikantor akuntan publik, tanpa memandang klasifikasi fungsinya (misalnya, audit, pajak, atau konsultasi), semuanya melakukan penyediaan jasa professional.

\section{Pengembangan Hipotesis Pengaruh (IPK) Indeks Prestasi Kumulatif terhadap Pemilihan Profesi Akuntan Publik}

Pelaksanaan pemeriksaan haruslah seorang yang memiliki pendidikan, pengalaman dan keahlian dibidang akuntansi, perpajakan, sistem akuntansi dan pemeriksaan akuntan (Agoes, 2012:5), Artinya IPK dapat menggambarkan pendidikan, prestasi dan keahlian mahasiswa studi akuntansi terkait mempertimbangkan pilihannya dalam memilih sebuah profesi, sehingga dapat mempengaruhi pilihannya tentang profesi akuntan disektor publik. Pada penelitian Siregar (2006), dalam penelitiannya menunjukan Indeks Prestasi Akademik mempengaruhi pemilihan karir mahasiswa akuntansi.

H1: Diduga persepsi mahasiswa mengenai indeks prestasi kumulatif, berpengaruh positif dan signifikan terhadap pemilihan profesi akuntan publik.

\section{Pengaruh Penghargaan Finansial terhadap Pemilihan Profesi Akuntan Publik}

Penghargaan finansial menjadi satu dari beberapa alasan seseorang bekerja dan merupakan alasan paling utama diantara yang lain untuk berafiliasi dengan orang lain,, berprestasi, mengembangkan diri, lalu untuk mengaktualisasikan diri (Kadarisman, 2012:329), Artinya penghargaan finansial menjadi pertimbangan saat pemilihan suatu profesi karena tujuan utama seseorang bekerja adalah mendapatkan gaji, sehingga bisa mempengaruhi pemilihan profesi akuntan disektor publik. Zaid (2015), apriliawati (2014), dan Wahyuningtiyas (2012) dalam penelitiannya menunjukan bahwa penghargaan finansial mempengruhi pemlihan profesi sebagai akuntan publik.

H2: Diduga persepsi mahasiswa mengenai penghargaan finansial, berpengaruh positif dan signifikan terhadap pemilihan profesi akuntan publik.

\section{Pengaruh Lingkungan Kerja terhadap Pemilihan Profesi Akuntan Publik}

Lingkungan kerja ialah prihal yang menjadi sifat pekerjaan, nilai persaingan dan tingginya beban kerja (Sembiring, 2009:54), Artinya lingkungan kerja bisa menjadi pertimbangan dan ketertarikan mahasiswa sebagai calon pemilih profesi ataupun tenaga kerja dalam memilih sebuah profesi. sehingga bisa mempengaruhi pemlihan profesi akuntan publik. Iswahudin (2015), dan Apriliyan (2011), dalam penelitiannya menunjukkan lingkungan kerja mempengaruhi pemilihan 
karir mahasiswa jurusan akuntansi sebagai akuntan publik.

H3: Diduga persepsi mahasiswa mengenai lingkungan kerja, berpengaruh positif dan signifikan terhadap pemilihan profesi akuntan publik.

\section{METODE PENELITIAN}

Penelitian ini meneliti tentang persepsi mahasiswa mengenai pengaruh indeks prestasi kumulatif, penghargaan finansial dan lingkungan kerja terhadap pemilihan profesi akuntan publik. Penelitian ini ialah penelitian kuantitatif. Penelitian ini dikategorikan metode penelitian survei memiliki sifat deskriptif, dengan teknik asosiatif kausal. Penggunaan teknik asosiatif kausal yaitu melakukan uji hipotesis hubungan variabel sebanyak 2 ataupun lebih yang mengandung sebab akibat dan biasanya diawali dengan kata pengaruh atau faktor determinan.

\section{Variabel Penelitian dan Operasionalisasi Variabel}

Variabel Independent (variabel bebas) adalah IPK $\left(\mathrm{X}_{1}\right)$, Penghargaan Finansial $\left(\mathrm{X}_{2}\right)$, dan Lingkungan Kerja $\left(\mathrm{X}_{3}\right)$. Variabel Dependent adalah (variabel terikat) Pemilihan Profesi Akuntan Publik. Indikator pada penelitian ditunjukan pada tabel 1 : 
66 | Persepsi Mahasiswa Mengenai Pengaruh IPK (Indeks Prestasi Kumulatif)...

Tabel 1 Operasional Variabel

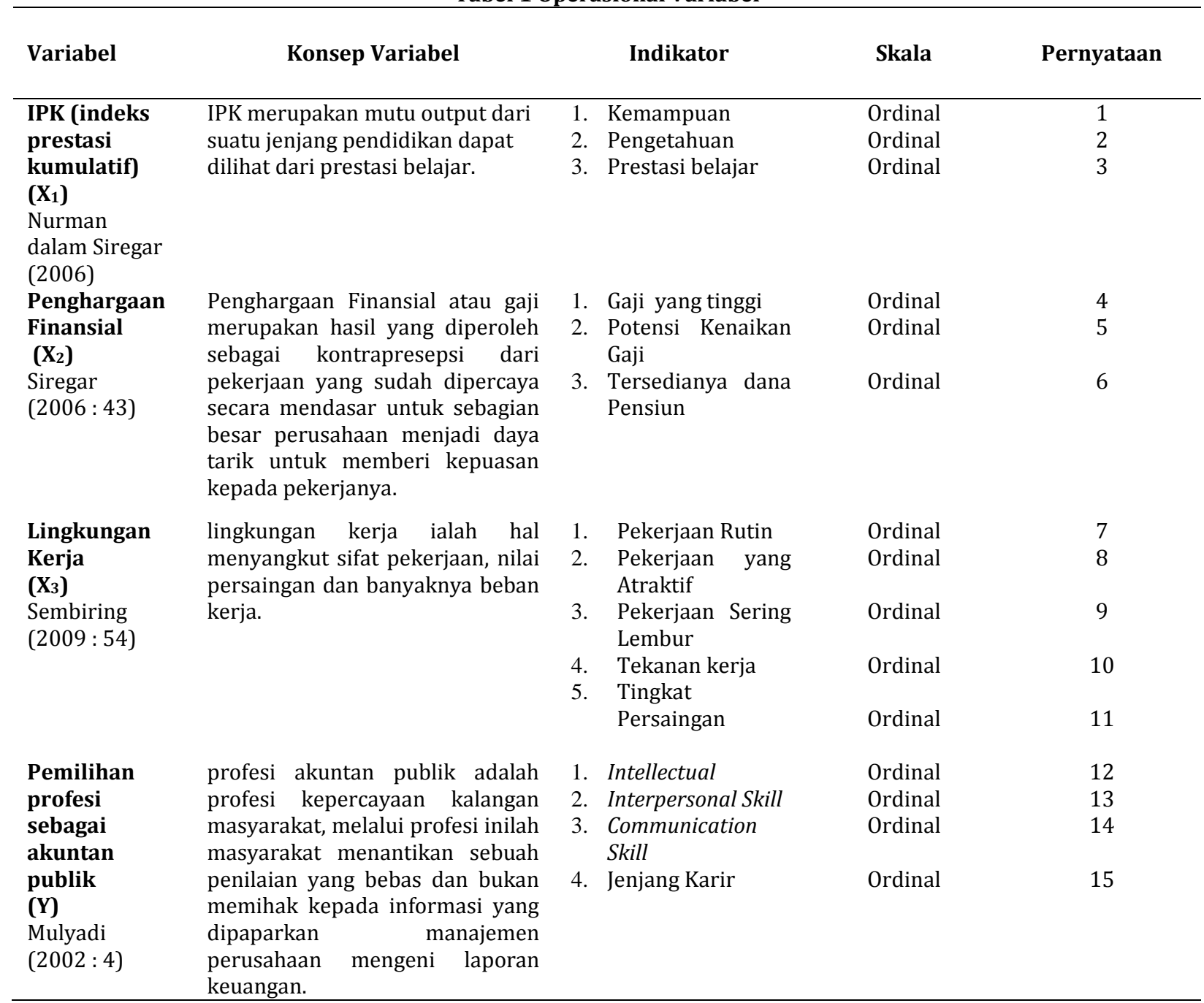




\section{Populasi, Sampel dan Teknik Pengambilan Sampel}

Populasi penelitian digunakan adalah mahasiswa program studi S1 akuntansi perguruan tinggi diKota Bogor. Untuk pemilihan sampel menggunakan proportionate stratified random sampling dngan kriteria mahasiswa berstatus aktif dan telah mengambil mata kuliah audit.

Hal tersebut menjadikan penelitian mengunakan sampel data mahasiswa sesuai kriteria yaitu 273 responden.

\section{Pengujian Instrumen}

Berdasarkan data penelitian berupa kuesioner menurut Sugiyono (2013:136) data dapat diolah dengan skala pengukuran likert. Pengolahan data ordinal menjadi analisis regresi terlebih dahulu diharuskan ditransformaskan kebentuk data interval. Berikut rumusnya :

$$
\frac{\text { Nilai Tertinggi-Nilai Terendah }}{\text { Banyaknya kelas }}=\frac{5-1}{5}=0,8
$$

Berdasarkan hasil perhitungan panjang kelas interval tersebut diperoleh kriteria penilaian pada Tabel 2 :

\begin{tabular}{cc}
\multicolumn{2}{c}{ Tabel 2 : Skala Penelitian } \\
\hline Skala & Interpretasi \\
\hline $\mathbf{1 , 0 0}-\mathbf{1 , 8 0}$ & Sangat Tidak Baik \\
$\mathbf{1 , 8 1}-\mathbf{2 , 6 0}$ & Tidak Baik \\
$\mathbf{2 , 6 1}-\mathbf{3 , 4 0}$ & Cukup \\
$\mathbf{3 , 4 1}-\mathbf{4 , 2 0}$ & Baik \\
$\mathbf{4 , 2 1}-\mathbf{5 , 0 0}$ & Sangat Baik \\
\hline Sumber : Sugiyono, 2014 &
\end{tabular}

\section{Pengujian Validitas}

Ghozali (2011:52), uji validitas berguna untuk mengukur valid atau tidak kuesioner. Sugiyono (2013:183) Item instrumen dianggap valid jika koefisien sama dengan atau $>0,3$, jika kurang dari 0,3 maka item instrumen tersebut dinyatakan tidak valid.

Tabel 3 : Kriteria Uji Validitas

\begin{tabular}{cc}
\hline $\begin{array}{c}\text { Corrected Item Total } \\
\text { Corelation }\end{array}$ & Keterangan \\
\hline $\mathbf{0 0 , 3}$ & Valid \\
$<\mathbf{0 , 3}$ & Tidak Valid \\
\hline Sumber : Sugiyono, 2013 &
\end{tabular}

\section{Pengujian Reliabilitas}

Sugiyono (2011:183), Uji Reliabilitas adalah pengukuran yang berkali kali menghasilkan data yang sama atau konsisten. Hasil pengujian reliabilitas menunjukan seberapa jauh suatu alat ukur mampu dipercayai atau diandalkan melalui uji validitas lalu dinyatakan valid. Pengujian reliabilitas menggunkn rumus Alpha Cronbach. Kriteria instrumen penelitian dibilang reliabel berdasarkan teknik ini, yaitu apabila reliabilitas instrumen rhitung $\geq 0,6$.

Tabel 4 : Kriteria Uji Reliabilitas

\begin{tabular}{cc}
\hline Alpha Cronbach & Keterangan \\
\hline $\mathbf{2 0 , 6}$ & Reliabel \\
$<\mathbf{0 , 6}$ & Tidak Reliabel \\
\hline Sumber : Sugiyono, 2007 &
\end{tabular}

\section{Uji Asumsi Klasik}

Pengujian hipotesis dilakukan sebelum terlebih dahulu dilakukannya uji asumsi klasik yang mendasari penggunaan analisis regresi berganda. Persamaan regresi bisa disebut baik untuk menunjukan hubungan fungsional kelompok variabel tidak bebas kalau persamaan tersebut mencukupi asumsiasumsi regresi. Untuk melaksanakan uji asumsi klasik dat primer, jadi penelitian ini melakukan uji normalitas, uji multikolonieritas, dan uji heteroskedastisitas.

\section{Metode Analisis Data}

Bentuk persamaan regresi yang dirumuskan berdasarkan hipotesis yang dikembangkan yaitu sebagai berikut (Riduan, 2012:252):

$$
\mathrm{Y}=\mathrm{a}+\beta_{1} \mathrm{X}_{1}+\beta_{2} \mathrm{X}_{2}+\beta_{3} \mathrm{X}_{3}+\varepsilon
$$

Dimana :

$$
\begin{array}{ll}
\mathrm{Y} & =\text { Pemilihan Profesi Akuntan Publik } \\
\mathrm{a} & =\text { Nilai Konstanta } \\
\mathrm{X}_{1} & =\text { IPK } \\
\mathrm{X}_{2} & =\text { Penghargaan Finansial } \\
\mathrm{X}_{3} & =\text { Lingkungan Kerja } \\
\varepsilon & =\text { Error } \\
\beta_{1} & =\text { Koefisien regresi variabel } \mathrm{X}_{1} \\
\beta_{2} & =\text { Koefisien regresi variabel } \mathrm{X}_{2} \\
\beta_{3} & =\text { Koefisien regresi variabel } \mathrm{X}_{3}
\end{array}
$$

\section{Koefisien Determinasi ( $\mathbf{R}^{2}$ )}

Sugiyono (2013:207), koefisien determinasi (R Square $/ R^{2}$ ) dilakukan demi mengetahui presentase kontribusi pengaruh variabel independen IPK, Penghargaan Finansial dan Lingkungan Kerja secara bersama-bersama terhadap variabel dependen Pemilihan Profesi Akuntan Publik. Adapun untuk mengukur mengukur koefisien determinasi rumus yang digunakan ialah: 
68 | Persepsi Mahasiswa Mengenai Pengaruh IPK (Indeks Prestasi Kumulatif)...

$$
K D=r^{2} \times 100 \%
$$

\section{Uji Hipotesis \\ Uji Simultan (f-test)}

Semua variabel bebas yang mempunyai pengaruh maupun tidak terhadap variabel dependent dapat diketahui dengan Uji $\mathrm{F}$. Priyatno (2013:48) Uji statistik $F$ atau uji koefisien regresi secara serentak, yaitu uji yang dilakukan demi mengetahui apakah terdapat pengaruh antara IPK, Penghargaan Finansial dan Lingkungan Kerja secara bersama-sama atau secara simultan terhadap Pemilihan Profesi Akuntan Publik.

\section{Uji Parsial (t-test)}

Pengaruh variabel independent secara individual terhadap variabel dependent dapat diketahui dengan melakukan uji t. Menurut Priyatno (2013:50) Uji t dimaksudkan demi mengetahui pengaruh variabel independent (bebas) terhadap variabel dependent (terikat) secara individual atau secara parsial. Pengujian prihal penelitian ini ialah signifikansi dan koefisiensi regresi. Pengambilan keputusan didapatkan atas dasar bandingan nilai thitung masing-masing koefisien regresi dengan nilai t tabel sesuai dengan $\alpha=$ 0,05 .

\section{HASIL DAN PEMBAHASAN}

\section{Deskripsi dan Karakteristik Responden}

Dilakukannya penelitian ini pada mahasiswa S.1 program studi Akuntansi yang berstatus aktif di Kota Bogor dengan responden 273 mahasiswa. Pengumpulan data dilaksanakan dengan cara menyebar kuesioner lngsung kpada mahasiswa. Peneliti menyebar 300 kuesioner untuk meminimalisir kuesioner yang cacat dan tidak kembali, maka di sebar melebihi kebutuhan data penelitian sehingga kuesioner dapat terpenuhi dan digunakan sebagai data penelitian. Dari jumlah kuesioner yang disebar sebanyak 300, semua responden bersedia mengisi kuesioner dan dari total tersebut terdapat kuesioner yang tidak terisi sempurna/rusak yaitu sebanyak 17 kuesioner. Kemudian kuesioner telah diterima disleksi kembali untuk mendapatkan kuesioner cocok berdasarkan kebutuhan penelitian. karena penelitian ini hanya di butuhkan responden sebanyak 273 mahasiswa, kemudian bisa disimpulkn bahwa kuesioner $100 \%$ terpenuhi dengan mengambil
273 kuesioner sebagai data penelitian dari 300 kuesioner yang telah disebar dan mengabaikan kuesioner yang tidak terisi sempurna/rusak. Yang menjadi sampel ditunjukan Tabel 5 :

\begin{tabular}{cccc}
\multicolumn{4}{c}{ Tabel 5 : Rekapitulasi Karakteistik Responden } \\
\hline No & $\begin{array}{c}\text { Kriteria } \\
\text { Responden }\end{array}$ & Karakteristik & $\begin{array}{c}\text { Jumlah/ } \\
\text { orang }\end{array}$ \\
\hline $\mathbf{1}$ & Jenis Kelamin & Perempuan & $180(66 \%)$ \\
$\mathbf{2}$ & Usia & $21-25$ Th & $221(81 \%)$ \\
$\mathbf{3}$ & Latar Belakang & IPS & $110(40 \%)$ \\
& Pendidikan & & \\
\hline
\end{tabular}

Sumber: Data diolah,2017

Berdasarkan tabel 5 menggambarkan bahwa karakteristik responden didalam penelitian ini didominasi oleh perempuan yakni sebanyak 180 orang, dengan usia responden berkisar diantara 21-25 tahun yakni sebanyak 221 orang, dan dilatarbelakangi pendidikan berasal dari SMA dengan jurusan IPS. Berdasarkan dengan karakteristik tersebut, kesimpulannya ialah mahasiswa S-1 akuntansi perguruan tinggi di Kota Bogor yang berstatus aktif berada pada usia yang produktif atas pendidikan dengan latar belakang yang berkaitan dengan jurusan terpilih pada saat SMA dan dianggap telah memahami dalam melakukan penyusunan dan membaca laporan keuangan serta lebih matang dalam mempertimbangkan dipilihnya profesi akuntan publik demi jenjang karirnya.

\section{IPK (Indeks Prestasi Kumulatif)}

Rekapitulasi skor tanggapan mengenai IPK terlihat ditabel 6:

Tabel 6 Rekapitulasi Skor Tanggapan Variabel IPK

\begin{tabular}{|c|c|c|c|}
\hline \multirow{2}{*}{$\frac{\text { No }}{1}$} & Pernyataan & Jawaban & Ket \\
\hline & $\begin{array}{l}\text { Menjadi seorang akuntan } \\
\text { publik harus berpendidikan. }\end{array}$ & 4,28 & $\begin{array}{l}\text { Sangat } \\
\text { Setuju }\end{array}$ \\
\hline 2 & $\begin{array}{l}\text { Besarnya IPK } \\
\text { menggambarkan keahlian } \\
\text { seseorang. }\end{array}$ & 4,08 & Setuju \\
\hline \multirow[t]{3}{*}{3} & $\begin{array}{l}\text { IPK menjadi hal penting } \\
\text { dalam memilih suatu } \\
\text { pekerjaan. }\end{array}$ & 4,32 & $\begin{array}{l}\text { Sangat } \\
\text { Setuju }\end{array}$ \\
\hline & Total & 12,68 & \\
\hline & Nilai Rata-Rata & 4,22 & $\begin{array}{l}\text { Sangat } \\
\text { Setuju }\end{array}$ \\
\hline
\end{tabular}

Sumber: Data diolah,2017

\section{Penghargaan Finansial}

Rekapitulasi skor tanggapan

penghargaan finansial terlihat di Tabel 7 :

Tabel 7 : Rekapitulasi Skor Tanggapan Variabel Penghargaan Finansial

\begin{tabular}{clcc}
\hline \multicolumn{4}{c}{ Penghargaan Finansial } \\
\hline No & \multicolumn{1}{c}{ Pernyataan } & Jawaban & Ket \\
\hline $\mathbf{1}$ & $\begin{array}{l}\text { Anda mengharapkan gaji } \\
\text { yang besar dari profesi }\end{array}$ & 4,22 & $\begin{array}{l}\text { Sangat } \\
\text { Setuju }\end{array}$ \\
$\mathbf{2}$ & $\begin{array}{l}\text { Akuntan publik. } \\
\text { Anda mengharapkan } \\
\text { kenaikan gaji yang lebih }\end{array}$ & 4,15 & Setuju \\
\hline
\end{tabular}


cepat dari profesi akuntan

publik.

3 Anda mengharapkan mendapatan dana pensiun dari profesi akuntan publik Total Nilai Rata-Rata

Sumber: Data diolah,2017

\section{LIngkungan Kerja}

Rekapitulasi skor tanggapan mengenai lingkungan kerja terlihat di Tabel 8 :

Tabel 8 : Rekapitulasi Skor Tanggapan Variabel Lingkungan Kerja

\begin{tabular}{|c|c|c|c|}
\hline No & Pernyataan & Jawaban & Ket \\
\hline 1 & $\begin{array}{l}\text { Profesi akuntan publik } \\
\text { merupakan jenis pekerjaan } \\
\text { yang dilakukan secara rutin. }\end{array}$ & 3,84 & Setuju \\
\hline 2 & $\begin{array}{l}\text { Profesi akuntan publik } \\
\text { merupakan pekerjaan yang } \\
\text { dapat diselesaikan dengan } \\
\text { cepat }\end{array}$ & 3,75 & Setuju \\
\hline 3 & $\begin{array}{l}\text { Profesi akuntan publik } \\
\text { merupakan jenis pekerjaan } \\
\text { yang sering lembur. }\end{array}$ & 3,87 & Setuju \\
\hline 4 & $\begin{array}{l}\text { profesi akuntan publik } \\
\text { merupakan pekerjaan yang } \\
\text { terdapat tekanan } \\
\text { didalamnya untuk mencapai } \\
\text { hasil yang sempurna. }\end{array}$ & 3,95 & Setuju \\
\hline 5 & $\begin{array}{l}\text { Tingkat kompetisi antar } \\
\text { profesi akuntan publik } \\
\text { sangat tinggi. }\end{array}$ & 4,05 & Setuju \\
\hline & $\begin{array}{c}\text { Total } \\
\text { Nilai Rata-Rata }\end{array}$ & $\begin{array}{c}19,46 \\
3,89\end{array}$ & Setuju \\
\hline
\end{tabular}

Sumber: Data diolah,2017

\section{Pemilihan Profesi Akuntan Publik}

Rekapitulasi skor tanggapan mengenai pemilihan profesi akuntan publik terlihatdi Tabel 9:

Tabel 9 : Rekapitulasi Skor Tanggapan Variabel profesi akuntan publik

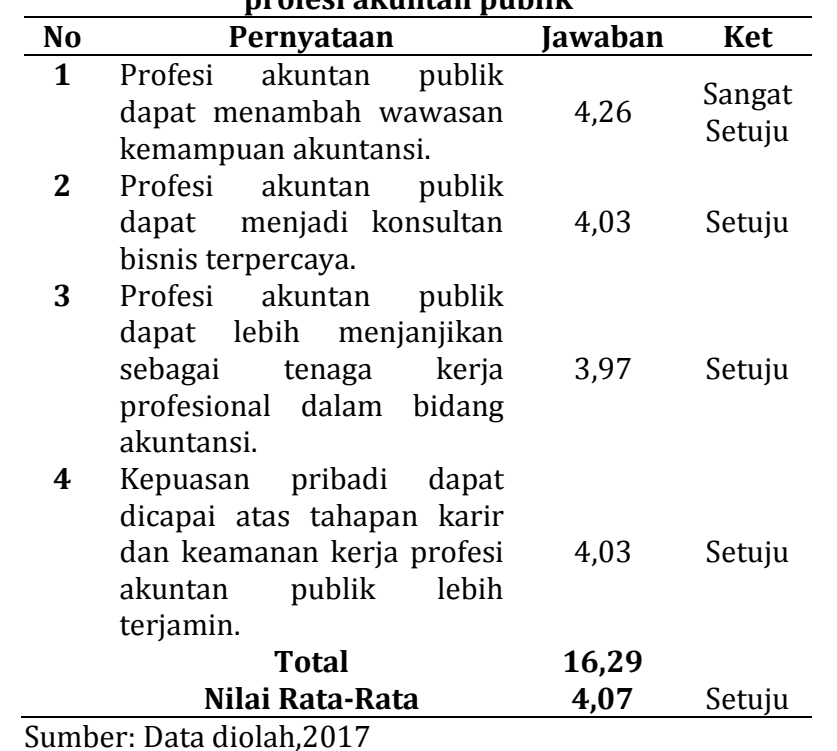

Sumber: Data diolah,2017

\section{Koefisien Determinasi}

Koefisien determinasi dilakukan untuk mengetahui besarnya kontribusi variabel IPK, penghargaan finansial dan lingkungan kerja terhadap pemilihan profesi akuntan publik. Koefisien determinasi didapat dengan (2)mengkuadratkan koefisien korelasi yang sudah didapatkan, kemudian kalikan dengan $100 \%\left(r^{2} \times 100 \%\right)$ atau juga langsung melihat nilai $\mathrm{R}$ Square $\left(\mathrm{R}^{2}\right)$. Hasil analisis koefisien determinasi terlihat pada tabel 10 berikut ini :

Tabel 10 : Koefisien Determinasi

\begin{tabular}{|c|c|c|c|c|}
\hline \multicolumn{5}{|c|}{ Model Summaryb } \\
\hline Model & $\mathrm{R}$ & $\begin{array}{c}\mathrm{R} \\
\text { Square }\end{array}$ & $\begin{array}{c}\text { Adjusted R } \\
\text { Square }\end{array}$ & $\begin{array}{l}\text { Std. Error of } \\
\text { the Estimate }\end{array}$ \\
\hline 1 & $634^{a}$ & ,402 & ,396 & 1,641 \\
\hline
\end{tabular}

a. Predictors: (Constant), lingkungan kerja,

penghargaan finansial, Indeks prestasi kumulatif (IPK)

b. Dependent Variable: Pemilihan Profesi Akuntan

Publik

Sumber: Output pengolahan data dengan SPSS 22, 2017

Berdasrkan Tabel 10 diperoleh $\mathrm{R}^{2}(R$

Square $(0,402)=(40,2 \%)$. Hal tersebut menggambarkan bahwa kontribusi IPK, penghargaan finansial dan lingkungan kerja terhadap pemilihan profesi akuntan publik sebesar 40,2\%, sedangkan sisanya 59,8\% dipengaruhi atau dijelaskan oleh variabel lain yang tidak dimasukan dalam model penelitian ini seperti gender, pertimbangan pasar kerja, pelatihan profesional, nilai-nilai sosial, pengakuan profesional. Standard Error of the Estimate adalah ukuran banyaknya kesalahan model regresi dalam memprediksi nilai Y. Dari hasil regresi didapat nilai 1.641 satuan, berarti banyaknya kesalahan dalam prediksi pemilihan profesi akuntan publik sebesar 1.641 satuan.

\section{Pengujian Instrumen Uji Validitas}

Uji validitas digunakan untuk mengetahui sejauhmana ketepatan pengukuran atau instrumen berguna untuk mengukur yang sehrusnya diukur. Instrumen yang valid berarti peralatan pengukur ini digunakan untuk mendapatkan data penelitian sudah tepat. Uji validitas dilakukan menghitung korelasi dianta masing-masing butir-butir pernyataan dengan skor jumlah pada masing-masing variabel. Nilai tersebut lalu dibandingkan dengan nilai $r_{\text {kritis. }}$ Hasil $u j i$ validitas variabel IPK $\left(\mathrm{X}_{1}\right)$, penghargaan finansial $\left(X_{2}\right)$, lingkungan kerja $\left(X_{3}\right)$, dan pemilihan profesi akuntan publik (Y), diuraikan pada tabel 11 : 
Tabel 11 : Hasil Uji Validitas

\begin{tabular}{|c|c|c|c|c|}
\hline No & Variabel & rhitung & rkritis & Ket \\
\hline 1 & $\begin{array}{l}\text { IPK (Indeks Prestasi } \\
\text { Kumulatif) }\end{array}$ & 0,609 & 0,3 & Valid \\
\hline 2 & Penghargaan Finansial & 0,634 & 0,3 & Valid \\
\hline 3 & Lingkungan Kerja & 0,554 & 0,3 & Valid \\
\hline 4 & $\begin{array}{l}\text { Pemilihan profesi } \\
\text { akuntan publik }\end{array}$ & 0,605 & 0,3 & Valid \\
\hline
\end{tabular}

Sumber: Output pengolahan data dengan SPSS 22,2017

Berdasarkan nilai tersebut ditentukan nilai standar (r-kritis) adalah sebesar 0,3 hal tersebut senada dengan yang disampaikan oleh Sugiyono (2013:182) yang menjelaskan bahwa ketika nilai hitung besarnya lebih dari atau $=0,3$ jadi data berarti valid. Semua pernyataan dari variabel independen (IPK (indeks prestasi kumulatif), penghargaan finansial, dan lingkungan kerja) dan variabel dependen yaitu pemilihan profesi akuntan publik dinyatakan valid karena $r_{\text {hitung }}$ masingmasing pernyataan $>$ dari $r_{\text {kritis. }}$

\section{Uji Reliabilitas}

Uji reliabilitas bertujuan untuk melihat apakah alat pengumpulan data yang dipakai, menunjukan drajat ketepatan, keakuratan, kestabilan dan konsistensi alat tersebut, dan hasil pengukuran tersebut akan tetap konsisten apabila dilakukan pengukuran kembali. Hasil uji reliabilitas menunjukan seberapa jauh konsistensi dan keterpercayaan atas hasil jawaban responden terhadap instrumen/pernyataan yang digunakan. Guna mengukur konsistensi interval penggunaan instrumen digunakan Cronbach Alpha, untuk mengetahui seluruh variabel dikatakan reliabel, rata-rata nilai Cronbach Alpha harus lebih $>$ atau $=0,6$. Hasil pengujian reliabilitas diuraikan Tabel 12 :

Tabel 12 : Hasil Uji Reliabilitas

\begin{tabular}{clccc}
\hline No & \multicolumn{1}{c}{ Variabel } & $\begin{array}{c}\text { Cronbach's } \\
\text { Alpha }\end{array}$ & rkritis & Ket \\
\hline $\mathbf{1}$ & $\begin{array}{l}\text { IPK (Indeks } \\
\text { Prestasi } \\
\text { Kumulatif) }\end{array}$ & 0,843 & 0,6 & Reliabel \\
$\mathbf{2}$ & $\begin{array}{l}\text { Penghargaan } \\
\text { Finansial }\end{array}$ & 0,787 & 0,6 & Reliabel \\
$\mathbf{3}$ & $\begin{array}{l}\text { Lingkungan } \\
\text { Kerja }\end{array}$ & 0,720 & 0,6 & Reliabel \\
$\mathbf{4}$ & $\begin{array}{l}\text { Pemilihan } \\
\text { profesi akuntan } \\
\text { publik }\end{array}$ & 0,782 & 0,6 & Reliabel \\
\hline Sumber: Output pengolahan data dengan SPSS 22,2017
\end{tabular}

Sumber: Output pengolahan data dengan SPSS 22,2017

Berdasarkan nilai tersebut ditentukan nilai standar (r-kritis) adalah sebesar 0,6 hal tersebut senada dengan yang disampaikan oleh Sugiyono (2013:184) yang menjelaskan bahwa suatu instrumen dinyatakan reliabel bila koefisien lebih dari atau $=0,6$. Semua pernyataan dari variabel independen (IPK (indeks prestasi kumulatif), penghargaan finansial, dan lingkungan kerja) dan variabel dependen yaitu pemilihan profesi akuntan publik dinyatakan reliabel karena Cronbach's Alplha masing-masing pernyataan $>$ dari $\mathrm{r}_{\text {kritis. }}$

\section{Hasil Analisa dan Pembahasan Analisa Regresi Berganda}

Analisis regresi linier berganda dipergunakan untuk memperlihatkan hubungaan fungsional antara beberapa variabel dependen secara bersama-sama terhadap variabel terikat, dan juga mengetahui jika variabel independen (bebas) dinaikan ataupun diturunkan nilainya. Hasil tersebut diuraikan Tabel 13 :

Tabel 13 : Analisis Regresi Linier Berganda

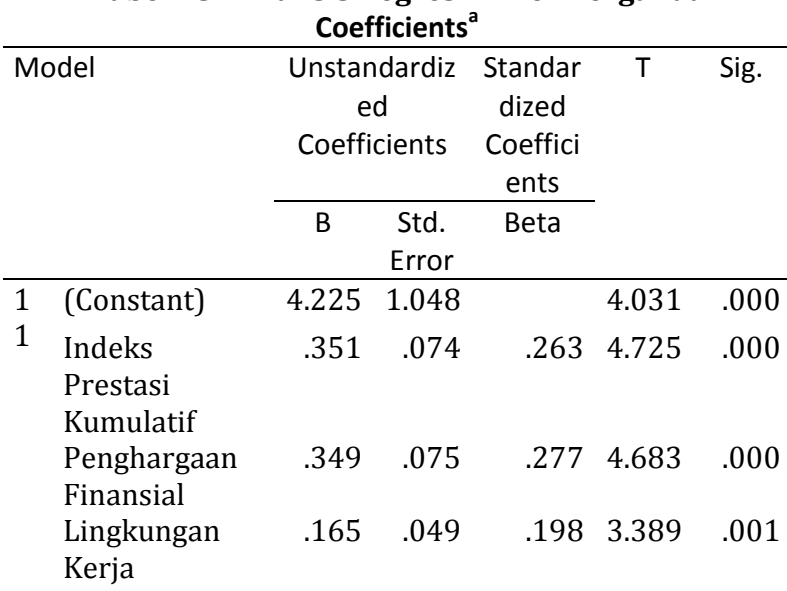

a. Dependent Variable: Pemilihan Profesi Akuntan Publik Sumber: Output pengolahan data dengan SPSS 22, 2017

Berdasarkan Tabel 11 di ketahui bahwa nilai persamaan regresi yaitu sebagai berikut :

$$
\begin{gathered}
y=a+b_{1} x_{1}+b_{2} x_{2}+b_{3} x_{3}+\varepsilon \\
y=\mathbf{4 . 2 2 5}+\mathbf{0 , 3 5 1} x_{1}+\mathbf{0 , 3 4 9} x_{2}+\mathbf{0 , 1 6 5} x_{3}+\varepsilon
\end{gathered}
$$

Interpretasi dari regresi tersebut yaitu:

1. Hasil persamaan regresi tersebut diperoleh nilai konstanta sebesar 4.225, nilai tersebut mempunyai arti bahwa jika seluruh variabel dependent yaitu IPK, penghargaan finansial dan lingkungan kerja bernilai 0 , maka pemilihan profesi akuntan publik bernilai 4.225 atau nilai pemilihan profesi akuntan publik tetap.

2. Hasil persamaan regresi untuk variabel IPK sebesar 0,351. Ini menghasilkan bahwa untuk setiap peningkatan IPK sebesar satu satuan, dengan asumsi variabel penghargaan finansial dan lingkungan kerja bernilai 0 , maka menyebabkan 
meningkatnya pemilihan profesi akuntan publik sebesar 0,351.

3. Hasil persamaan regresi untuk variabel penghargaan finansial sebesar 0,349. Hal tersebut menggambarkan jika untuk setiap peningkatan penghargaan finansial sebesar satu satuan, dengan asumsi variabel IPK dan lingkungan kerja bernilai 0 , maka menyebabkan meningkatnya pemilihan profesi akuntan publik sebesar 0,349.

4. Hasil persamaan regresi untuk variabel lingkungan kerja sebesar 0,165. Ini menghasilkan bahwa untuk setiap peningkatan lingkungan kerja sebesar satu satuan, dengan asumsi variabel IPK dan penghargaan finansial bernilai 0 , maka menyebabkan meningkatnya pemilihan profesi akuntan publik sebesar 0,165.

5. Berdasarkan tabel yang diuraikan menunjukan variabel IPK ialah variabel paling dominan dengan nilai 0,351, artinya IPK sangat mempengaruhi pertimabngan mahasiswa dalam memilih profesi akuntan publik.

\section{Pengujian Hipotesis}

\section{Uji F-test}

Pengujian dilakukan untuk mendapatii pengaruh simultan IPK, penghargaan finansial, dan lingkungan kerja terhadap pemilihan profesi akuntan publik. Maka hipotesis yang digunakan sebagai berikut:

$H_{0}: \beta_{1}, \beta_{2}, \beta_{3} \leq 0$; IPK, Penghargaan Finansial dan Lingkungan Kerja, secara simultan tidak mempunyai pengaruh terhadap variabel PEmilihan Profesi Akuntan Publik.

$H_{a}: \beta_{1}, \beta_{2}, \beta_{3}>0$; IPK, Penghargaan Finansial dan Lingkungan Kerja, secara simultan mempunyai pengaruh terhadap variabel Pemilihan Profesi Akuntan Publik.

Dari uji F dapat diperoleh melalui Tabel analisis varians (Anova) seperti yang diuraikan Tabel 14 :

\begin{tabular}{|c|c|c|c|c|c|}
\hline & $\begin{array}{r}\text { Tabe } \\
\mathrm{Al} \\
\end{array}$ & $\begin{array}{l}\text { 14: } \\
\text { JOVA }\end{array}$ & ji F & & \\
\hline Model & $\begin{array}{c}\text { Sum of } \\
\text { Squares }\end{array}$ & $\mathrm{Df}$ & $\begin{array}{c}\text { Mean } \\
\text { Square }\end{array}$ & $F$ & Sig. \\
\hline 1 Regression & 390,431 & 3 & 130,144 & 45,364 & $000^{\mathrm{b}}$ \\
\hline Residual & 771,723 & 269 & 2,869 & & \\
\hline Total & 1162,154 & 272 & & & \\
\hline
\end{tabular}

a. Dependent Variable: Pemilihan Profesi Akuntan Publik

b. Predictors: (Constant), Lingkungan Kerja, Indeks prestasi kumulatif, Penghargaan Finansial

Sumber: Output pengolahan data dengan SPSS 22, 2017
Tabel 14 tersebut telah diketahui bahwa hasil pengujian menggunakan uji $\mathrm{F}$,

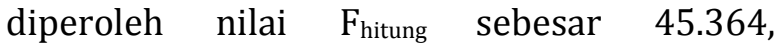
sedangkan nilai $F_{\text {tabel }}$ sebesar 3,79. Apabila $\mathrm{F}_{\text {hitung }}$ dibandingkan dengan $\mathrm{F}_{\text {tabel }}$, maka $\mathrm{F}_{\text {hitung }}>$ $F_{\text {tabel }}(45,364>3,79)$ dengan nilai signifikansi F sebesar $0,00<0,05$. Maka berarti $\mathrm{H}_{\mathrm{o}}$ ditolak dan $\mathrm{H}_{\mathrm{a}}$ diterima. Kondisi ini bermakna bahwa IPK, penghargaan finansial dan lingkungan kerja berpengaruh secara simultan terhadap pemilihan profesi akuntan publik.

\section{Uji t-test}

Pengujian digunakan demi menentukan pengaruh secara parsial IPK, penghargaan finansial, dan lingkungan kerja terhadap pemilihan profesi akuntan publik.. Maka hipotesis dilakukan yaitu sebagai berikut :

$\mathrm{H}_{\mathrm{o}}: \beta_{1} \leq 0$; IPK tidak berpengaruh terhadap pemilihan profesi akuntan publik.

$\mathrm{H}_{\mathrm{a}}: \beta_{1}>0$; IPK berpengaruh terhadap profesi pemilihan akuntan publik.

$\mathrm{H}_{\mathrm{o}}: \beta_{2} \leq 0$;Penghargaan finansial tidak berpengaruh terhadap pemilihan profesi akuntan publik.

$\mathrm{H}_{\mathrm{a}}: \beta_{2} \quad>0$;Penghargaan finansial berpengaruh terhadap pemilihan profesi akuntan publik.

$\mathrm{H}_{\mathrm{o}}: \beta_{3} \leq 0$;Lingkungan Kerja tidak berpengaruh terhadap pemilihan profesi akuntan publik.

$\mathrm{H}_{\mathrm{a}}: \beta_{3}>0$;Lingkungan Kerja berpengaruh terhadap pemilihan profesi akuntan publik.

Berdasarkan perhitungan diperoleh hasil berikut ini :

\begin{tabular}{|c|c|c|c|c|c|}
\hline \multirow[t]{2}{*}{ Model } & \multicolumn{2}{|c|}{$\begin{array}{l}\text { Unstandardize } \\
\text { d Coefficients }\end{array}$} & \multirow{2}{*}{$\begin{array}{c}\begin{array}{c}\text { Standardize } \\
\text { d } \\
\text { Coefficients }\end{array} \\
\text { Beta }\end{array}$} & \multirow[t]{2}{*}{$\mathrm{T}$} & \multirow[t]{2}{*}{ Sig. } \\
\hline & B & $\begin{array}{l}\text { Std. } \\
\text { Error }\end{array}$ & & & \\
\hline 1 (Constant) & 4,225 & 1,048 & & $\begin{array}{r}4,03 \\
1\end{array}$ & $\begin{array}{r}, 00 \\
0\end{array}$ \\
\hline $\begin{array}{l}\text { Indeks } \\
\text { Prestasi } \\
\text { Kumulatif }\end{array}$ & ,351 & ,074 & 263 & $\begin{array}{r}4,72 \\
5\end{array}$ & $\begin{array}{r}, 00 \\
0\end{array}$ \\
\hline $\begin{array}{l}\text { Penghargaa } \\
\text { n Finansial }\end{array}$ & 349 & 075, & 277, & $\begin{array}{r}4,68 \\
4\end{array}$ & $\begin{array}{r}, 00 \\
0\end{array}$ \\
\hline $\begin{array}{l}\text { Lingkungan } \\
\text { kerja }\end{array}$ & 156 & ,049 & 198 & $\begin{array}{r}3,38 \\
9\end{array}$ & $\begin{array}{r}, 00 \\
1\end{array}$ \\
\hline
\end{tabular}

a. Dependent Variable: Pemilihan Profesi Akuntan Publik Sumber: Output pengolahan data dengan SPSS 22, 2017
1. Uji t Variabel IPK (Indeks Prestasi Kumulatif) 
Hasil pengujian data menggunakan uji t diperoleh nilai $t_{\text {hitung }}$ untuk IPK sebesar 4.725, sedangkan nilai $t_{\text {tabel }}$ 1.968. Apabila $t_{\text {hitung }}$ dibandingkan dengan $t_{\text {tabel }}$ maka $t_{\text {hitung }}>t_{\text {tabel }}$ $(4.725>1.968)$ dengan tingkat signifikan $0.000<0.005$. Maka berarti $\mathrm{H}_{\mathrm{o}}$ ditolak dan $\mathrm{H}_{\mathrm{a}}$ diterima. Kondisi ini bermakna bahwa IPK secara parsial berpengaruh terhadap pemilihan profesi akuntan publik.

\section{Uji t Variabel Penghargaan Finansial}

Hasil uji mamakai uji t diperoleh nilai $t_{\text {hitung }}$ untuk penghargaan finansial sebesar 4.683, sedangkan nilai $t_{\text {tabel }} 1.968$. Apabila $t_{\text {hitung }}$ dibandingkan dengan $t_{\text {tabel }}$ maka $t_{\text {hitung }}>t_{\text {tabel }}$ $(4.683>1.968)$ dengan tingkat signifikan $0.000<0.005$. maka berarti bahwa $\mathrm{H}_{\mathrm{o}}$ ditolak dan $\mathrm{H}_{\mathrm{a}}$ diterima. Kondisi ini bermakna bahwa penghargaan finansial secara parsial berpengaruh terhadap pemilihan profesi akuntan publik.

\section{Uji t Variabel Lingkungan Kerja}

Hasil uji memakai uji t diperoleh nilai $t_{\text {hitung }}$ untuk lingkungan kerja sebesar 3.389, sedangkan nilai $t_{\text {tabel }}$ 1.968. Apabila $t_{\text {hitung }}$ dibandingkan dengan $t_{\text {tabel }}$ maka $t_{\text {hitung }}>t_{\text {tabel }}$ (3.389 > 1.968) dengan tingkat signifikan $0.001<0.005$. Maka berarti bahwa $\mathrm{H}_{\mathrm{o}}$ ditolak dan $\mathrm{H}_{\mathrm{a}}$ diterima. Kondisi ini bermakna bahwa lingkungan kerja secara parsial berpengaruh terhadap pemilihan profesi akuntan publik.

\section{Pembahasan}

\section{Uji F}

Berdasarkan hasil uji secara simultan menunjukan bahwa IPK, penghargaan finansial dan lingkungan kerja berpengaruh positif terhadap pemilihan profesi akuntan publik, artinya mahasiswa mempertimbangkan IPK dalam memilih profesi sebagai akuntan publik setelah pendidikannya selesai di perguruan tinggi. Pentingnya mahasiswa mempertimbangkan IPK dalam memilih profesi akuntan disektor publik karena IPK menjadi hasil pengukuran prestasi belajar berbentuk angka yang akan diterima mahasiswa. Mahasiswa menganggap semakin baik prestasi yang didapatkan dalam jenjang pendidikannya maka diharapkan akan semakin menggambarkan kinerja yang akan diberikannya saat seorang memilih untuk menjadi akuntan publik. Pentingnya mahasiswa mempertimbangkan penghargaan finansial didalam dipilihnya profesi akuntan disektor publik yaitu karena faktor utama yang menjadi tujuan dalam memilih sebuah profesi termasuk profesi akuntan publik adalah mendapatkan gaji, mahasiswa mempertimbangkan penghargaan finansial dari berprofesi sebagai akuntan publik yaitu dengan mengharapkan gaji awal yang tinggi, naiknya gaji yang relatif cepat serta penghargaan finansial nantinya diberikan kepada profesi akuntan publik dalam jangka panjang. Begitu pula dengan pertimbangan lingkungan kerja demi memilih profesi akuntan disektor publik, mahasiswa menganggap bahwa akuntan publik memliki lingkungan kerja atraktif/banyak memiliki tantangan, tingkat persaingan yang tinggi dan beban kerja untuk setiap prosesnya, hal ini terjadi karena selaku akuntan publik perlu mengerti karakter kliennya. Hal ini sejalan dengan teori Isnanto (2009:10), profesi ialah aktivitas yang dilakukan seperti kegiatan pokok seseorang demi memenuhi kebutuhan kehidupan dari mengandalkan suatu keahlian.

\section{Uji t}

\section{Pengaruh IPK (indeks prestasi Kumulatif)}

Berdasarkan hasil uji secara parsial variabel IPK mempengaruhi pemilihan profesi akuntan publik secara parsial. Hasil yang didapatkan membuktikan adanya pengaruh IPK terhadap terpilihnya profesi akuntan publik oleh mahasiswa S-1 akuntansi perguruan tinggi yang berstatus aktif di Kota Bogor. IPK menjadi pertimbangan didalam menentukan profesi karena para mahasiswa menyadari akan tujuannya dalam belajar di pergurun tinggi, dia pasti bersungguh sungguh mendorong diri mereka untuk belajar aktif dalam menyelesaikan beban studi yang telah direncanakan terlebih dahulu demi meneruskan ketahapan selanjutnya dalam memilih sebuah profesi. IPK bermanfaat membantu memprediksi keberhasilan mahasiswa diwaktu yang akan datang. Nilai yang diperolehnya bisa berguna sebagai patokan untuk menetapkan suatu keputusan untuk memilih sebuah profesi termasuk profesi akuntan publik ini. Perguruan tinggi menjadi fasilitas utama untuk dapat memotivasi dan menmberikan sistem pengajaran yang baik untuk membantu mahasiswa dalam mencapai prestasi dengan baik.

Hasil penelitian ini mendukung penelitian yang dilaksanakan Siregar (2006) mengungkapkan bahwa orang yang cerdas 
akan lebih bebas untuk menentukan jenis karir yang akan dijalankannya dan bisa mengharapkan timbalbalik lebih tinggi untuk kecerdasannya itu.

\section{Pengaruh Penghargaan Finansial}

Berdasarkan hasil uji variabel penghargaan finansial secara parsial berpengaruh positif terhadap pemilihan profesi akuntan publik. Hasil penelitian tersebut membuktikan bahwa adanya pengaruh penghargaan finansial dengan pemilihan profesi akuntan publik pada mahasiswa S-1 Akuntansi perguruan tinggi berstatus aktif di Kota Bogor karena penghargaan finansial merupakan balas jasa berbentuk matauang yang diterima karyawan karena kedudukannya di perusahaan yang memberikan kontribusi didalam memenuhi target perusahaan dan dipercayai mendasar untuk beberapa perusahaan sebagai daya tarik dalam memberikan sebuah kepuasan kepada karyawannya. Penghargaan finansial atau gaji menjadi pertimbangan karena pengguna jam kerja personil atau tim perikatan dalam setiap tahapan pekerjaan audit institut berguna memberikan ilustrasi dasar dalam perhitungan penetapan imbalan jasa akuntan publik halnya yang telah tercantum dalam peraturan.

Hasil ini mendukung penelitian yang dilaksanakan Zaid (2015) mengemukanan bahwa penghargaan finansial yang akan didapatkan profesi akuntan publik tinggi maka akan menambah keinginan mahasiswa untuk memilih profesi akuntan publik.

\section{Pengaruh Lingkungan Kerja}

Berdasarkan hasil uji variabel lingkungan kerja secara parsial berpengaruh secara positif terhadap pemilihan profesi akuntan publik. Hasil tersebut membuktikan bahwa adanya pengaruh $\left(\mathrm{X}^{2}\right)$ lingkungan kerja terhadap (Y) pemilihan profesi akuntan publik pada mahasiswa S-1 Akuntansi perguruan tinggi berstatus aktif di Kota Bogor sebab lingkungan kerja merupakan suatu pertimbangan didalam pemilihan profesi menjadi AP (akuntan Publik). Lingkungan kerja dijelaskan dengan pernyataan mengenai sifat pekerjaan, mewujudkan lingkungan kerja yang baik harus diprioritaskan, sebab lingkungan kerja menjadi prihal yang mempengaruhi karyawan maupun calon pekerja untuk bisa menunjukan kinerja terbaiknya untuk perusahaan. Seorang AP dituntut untuk mengertii karakter kliennya dalam segala kondisi yang sedang terjadi.

Hasil penelitian ini mendukung penelitian yang dillaksanakan Kurniawati (2016) mengemukakan bahwa lingkungan kerja dipertimbangkan didalam pemilihan profesi akuntan publik. Mahasiswa akuntansi memilih karir akuntan publik memandang lingkungan kerja akuntanpublik ialah lingkungan kerja yang lebih banyak dituntut demi menghadapi rintangan karena dengan bervariasinya jasa yang ditawarkan klien dapat menimbulkan berbagai macam tekanan kerja demi mencapai hasil sempurna, pekerjaan akuntan publik sendiri lebih atraktif, lebih membutuhkan waktu, nilai saingan dan banyak tekanan dalam pekerjaan yang maksimal.

\section{SIMPULAN}

1. Karakteristik responden dalam penelitian ini yaitu mahasiswa yang didominasi oleh mahasiswa perempuan ialah sejumlah 180 orang, dengan usia responden berkisar antara 21-25 tahun sebanyak 221 orang, dengan latar belakang pendidikan berasal dari jurusan IPS (Ilmu Pengetahuan Sosial) sebanyak 110 orang. Berdasarkan tanggapan responden mengenai penelitian ini, pada masingmasing variabel secara umum adalah setuju, namun untuk variabel IPK tanggapan responden adalah sangat setuju.

2. IPK, Penghargaan Finansial dan Lingkungan Kerja secara simultan berpengaruh positif terhadap pemilihan profesi akuntan publik.

3. IPK, Penghargaan Finansial dan Lingkungan Kerja secara parsial berpengruh positif terhadap pemilihan profesi akuntan publik

4. Berdasarkan hasil pengujian analisis regresi linear berganda dapat dketahui bahwa faktor yang paling dominan dalam pemlihan profesi akuntan publik pada mahasiswa S-1 akuntansi perguruan tinggi yang berstatus aktif diKota Bogor adalah IPK.

\section{DAFTAR PUSTAKA}


Agoes, Sukrisno, 2012, Auditing, Buku 1 Edisi 4. Salemba Empat, Jakarta.

Apriliyan, Lara Absar, 2011, Faktor-faktor yang Mempengaruhi Mahasiswa Akuntansi dalam Pemilihan Karir Menjadi Akuntan Publik (Study Empiris pada Mahasiswa Akuntansi UNDIP dan Mahasiswa Akuntansi UNIKA), Skripsi, Universitas Diponogoro Semerang.

Apriliawati, Devi Luciana, 2014, Persepsi Mahasiswa Akuntansi terhadap Faktor-Faktor yang mempengaruhi Pemilihan Karir, Skripsi, Fakultas Ekonomi dan Bisnis Jurusan Akuntansi, Universitas Brawijaya.

Asmoro, Tri Kusno Widi, Anita Wijayanti., \& Suhendro, 2016, Faktor - Faktor yang Mempengaruhi Mahasiswa Akuntansi dalam Pemilihan Karir sebagai Akuntan Publik, Jurnal Jeam Vol XV, Universitas Islam Batik Surakarta.

Badan Pemeriksa Keuangan, 2017, Sistem Informasi akuntan Publik. https://sikap.bpk.go.id/\#. Diakses 13 Maret 2017 pukul 13:47.

Ghozali, Imam, 2011, Aplikasi Analisis Multivariate dengan Program SPSS, Badan Penerbit Universitas Diponogoro, Semarang.

IAI, Global, 2016, Kejar Ketertinggalan Akuntan di ASEAN IAI Siapkan Sertifikasi dan Penataan Profesi, http://www.iaiglobal.or.id.

Diakses 1 Maret 2017 Pukul 12:46.

Institut Akuntan Publik Indonesia, 2016, Jumlah Akuntan Publik di Kota Bogor,http://iapi.or.id/Iapi/mem bership kap/membership kap/bo gor-570e1456bc52b.pdf, Diakses 24 April 2017 Pukul 15:55.

Mulyadi, 2002, Auditing, Buku Dua, Edisi Ke Enam, Salemba Empat, Jakarta.

Odia, \& Ogiedu, 2013, Factors Affecting the Study of Accounting in Nigerian Universities, Journal of Educational and Social Research MCSER Publishing, Rome-Italy, Vol 3 No 3, Department of Accounting, University of Benin, Benin City, Nigeria.
Priyatno, Dwi, 2013, Analisis Korelasi Regresi dan Multivariate dengan SPSS, Gava Media, Yogyakarta.

Putra, Eka Wirmie, 2011, Analisis Perbedaan Persepsi Mahasiswa Akuntansi Universitas Jambi Mengenai Faktor - Faktor yang Mempengaruhi Pemilihan Karir, Jurnal Investasi, Vol 7 No 1, Hal 113, Universitas Jambi.

Salso, Robert. L., Maclin, Otto. H \& Maclin,M.Kimberly, 2007, Pisikologi Kognitif. Jakarta: Erlangga.

Sembiring, M. S., 2009, Faktor-Faktor Yang Mempengaruhi Pemilihan Karir Menjadi Akuntan Publik Oleh Mahasiswa Departemen Akuntansi Fakultas Ekonomi USU Medan, Tesis, Medan: Universitas Sumatera Utara.

Siregar R., 2006, Pengaruh Indeks Prestasi Kumulatif dan Persepsi Mahasiswa Akuntansi Kota Medan Mengenai Beberapa Faktor Tertentu Terhadap Pilihan Karir, skripsi, Medan: Program Pasca Sarjana Universitas Sumatera Utara.

Sugiyono, 2007, Metode Pendekatan Bisnis Pendekatan Kuantitatif Kualitatif \& RND. Alfabeta. Bandung.

2011. Metode penelitian pendidikan, Alfabeta. Bandung.

2013,Metode Penelitian Pendidikan (Pendekatan Kuantitatif, Kualitatif, dan R\&D), Alfabeta. Bandung.

2014, Metode Penelitian Kuantitatif, Kualitatif, dan Kombinasi (Mixed Methods). Alfabeta. Bandung.

Sutrisno, Edi, 2009, Manajemen Sumber Daya Manusia Edisi pertama, Jakarta: Kencana Prenada Media Group.

Veithzal Rivai \& Ella Jauvani Sagala, 2011, Manajemen Sumber Daya Manusia untuk Perusahaan, Jakarta: Rajawali Pers.

Zaid, Ikhwan Muhammad, 2015, Pengaruh Gender, Penghargaan Finansial dan Pertimbangan Pasar Kerja terhadap Minat Mahasiswa 


\begin{abstract}
Akuntansi untuk Berkarir menjadi Akuntan Publik, Skripsi, Program Studi Pendidikan Akuntansi, Fakultas Ekonomi, Universitas Negeri Yogjakarta.
\end{abstract}

